\title{
Tekmeria
}

Vol 13 (2016)

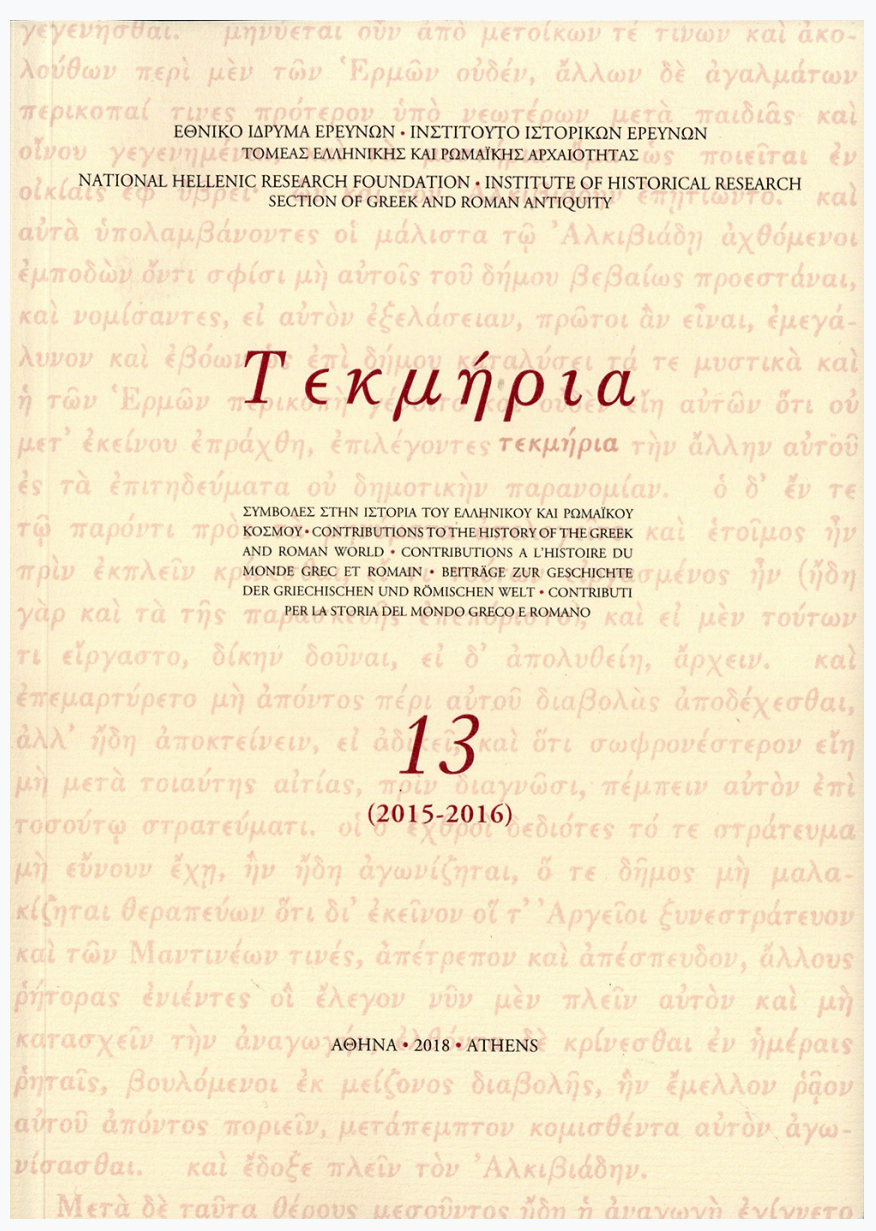

\section{Two new gladiatorial monuments from Amphipolis}

Pantelis Nigdelis, Anny Tzelepidou

doi: $10.12681 /$ tekmeria.10788

Copyright (c) 2017, Pantelis Nigdelis, Anny Tzelepidou

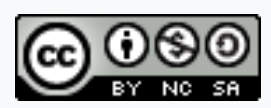

This work is licensed under a Creative Commons Attribution-NonCommercialShareAlike 4.0.

\section{To cite this article:}

Nigdelis, P., \& Tzelepidou, A. (2017). Two new gladiatorial monuments from Amphipolis. Tekmeria, 13, 71-78. https://doi.org/10.12681/tekmeria.10788 


\section{PANTELIS NIGDELIS, ANNY TZELEPIDOU}

\section{Two new gladiatorial monuments from Amphipolis}

Unlike other Macedonian cities as Beroia ${ }^{1}$ and Thessaloniki, ${ }^{2}$ where a lot of gladiatorial monuments have come to light, until recently only one gladiatorial inscription was known from Amphipolis, namely the funerary epigram in memory of a certain Euchrous. ${ }^{3}$

In addition to Euchrous' epigram, two new funeral inscriptions should be added to the gladiatorial inscriptions of Amphipolis. The first ${ }^{4}$ was inscribed on a reused marble funeral stele, which was later used for a third time as the cover of a cist-grave (T9). ${ }^{5}$ The grave is part of a cluster consisting of nine

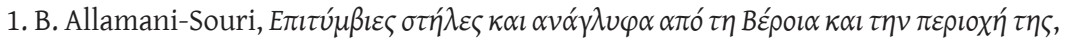

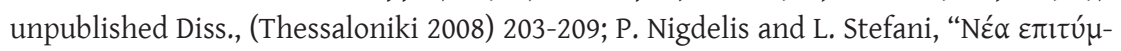

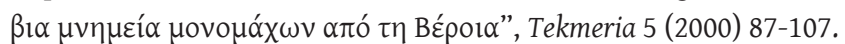

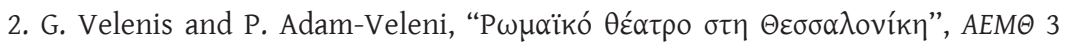
(1989) [1992] 241-256.

3. J. Roger, RA 24 (1945.2) 51-53 no. 4; L. Robert, "Monuments de Gladiateurs dans l'Orient Grec", Hellenica 5 (1948) 77-78, no. 314 = SEG LV 672; W. Peek, GV I 732 = SEG XXIV 599. D. Hereward (Palaeologia XIV 1968, 140/2 n. 10, c. del. fig. 12 = SEG XXIV 607) falsely mentions the inscription as unpublished.

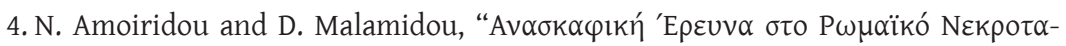

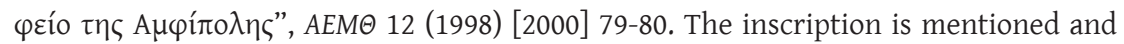
discussed in: M. B. Hatzopoulos, BullÉpigr 2001 no. 303; SEG XLIX 677; D. Malamidou, AA 52 B3 (1997) [2003] 840 (SEG LIII 591); D. Blackman, "Archaeology in Greece 2000-2001”,

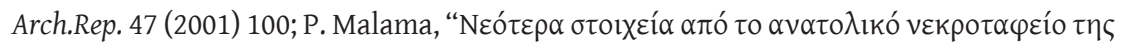

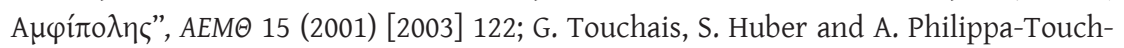
ais, "Chronique des fouilles et découvertes archéologiques en Grèce en 1999", BCH 124 (2000) 943-945; C. Mann, “Um keinen Kranz, um das Leben kämpfen wir!" Gladiatoren im Osten des römischen Reiches und die Frage der Romanisierung (Berlin 2011) 191 no 21.

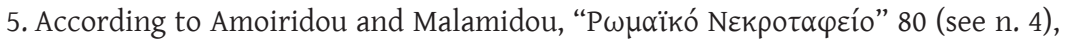
the stele was used three times: first, as funerary monument during the Hellenistic period; second, as the grave monument of the gladiator Achilles; thirdly, as the cover of the grave (T9) of a local doctor. 
burials excavated in a plot near the gate D of the city. As a silver denarius that is dated to the reign of Antoninus Pius (138-161) was found in the T9, the year 161 is the terminus ante quem for the third use of the stone, thus we can safely argue that the inscription was engraved at least some years earlier. ${ }^{6}$ The dating of the inscription could be also supported by the paleographical evidence. ${ }^{7}$

The new stele bears a relief representing a gladiator in a shallow rectangular panel, twelve engraved crowns on the left-hand side and at the bottom, as well as an engraved palm branch $\left(\sigma \pi \alpha \dot{\delta} \delta\llcorner)\right.$ on the right. ${ }^{8}$ The scene on the rectangular panel resembles the relief of the funeral stele for the gladiator Sulpicius found in Beroia (EKM I, 387). The gladiator is depicted advancing to the right, thus he is classified in Robert's second category "le gladiateur combatant", i.e. a gladiator who is represented in combat carrying his defensive and offensive weaponry. ${ }^{9}$ The deceased appears as a heavy armored gladiator, namely a secutor, ${ }^{10}$ wearing a chitoniskos with short sleeves as well as a belt (balteus). ${ }^{11}$ His left shin is protected by a greave (ocrea), while his right has a kind of protective lining. His right arm is wrapped in leather bands (manicae) and in that hand he holds a dagger. He also carries a shield (scutum) with his left arm and is equipped with a visored helmet and a metal crest. ${ }^{12}$

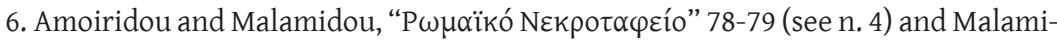
dou 840 (see n. 4).

7. The characteristic letters are: The three-bar sigma, the omega (with its lower part open) and the epsilon (squared, with its two horizontal bars of equal length and its middle smaller). An epigraphic parallel regarding the overall impression of its lettering is IGBulg IV 2304 (Kovačevo, 162 AD).

8. For representations of $\sigma \pi \alpha \dot{\delta} \delta\llcorner\xi$ see M. Carter, The Presentation of Gladiatorial Spectacles in the Greek East: Roman Culture and Greek Identity, Diss. (Michigan 1999) 98-103.

9. L. Robert, Les Gladiateurs dans l'Orient Grec (Amsterdam 1971) 47.

10. On this category and the relevant armor see M. Grant, Gladiators (Great Britain 1967) 60.

11. For such belts worn by secutores see Grant, Gladiators 60 (see n. 10).

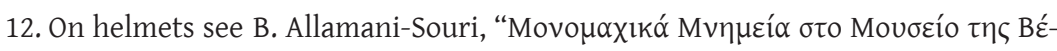

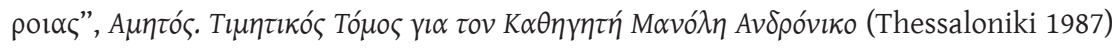
38 , no. B3. 
Archaeological Museum of Amphipolis, Inv. No. MK $\Lambda$ 144. Height 0.76 m.; upper width $0.26 \mathrm{~m}$;; lower width $0.24 \mathrm{~m}$.; thickness $0.076 \mathrm{~m}$. Letter height $0.02-0.026 \mathrm{~m}$. Line spacing: $0.01-0.012$ m. (fig. 1).

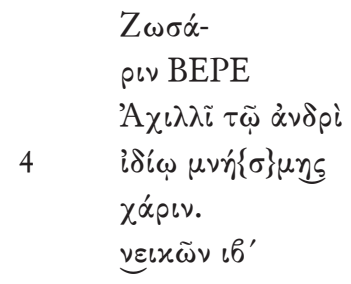

L. $4 \mathrm{MNH} \Sigma \mathrm{MH} \Sigma$ lapis.

Achilles, the professional name of the deceased, belongs to the category of heroic names which owners of gladiatorial schools usually gave to their fighting personnel. ${ }^{13}$ Achilles was given the name possibly because of his speed and his martial ability. ${ }^{14}$ The selection of such names implies that the spectators were familiar with the Homeric Epics and their heroic context; moreover, this choice demonstrates the wider trend observed in gladiatorial monuments in the Greek East of depicting gladiators' combats like $\mu$ ovo $\mu \alpha \chi i \alpha \iota$ of Homeric Epics, in order to familiarize the Greek or Hellenized audience with Roman spectacle. ${ }^{15}$

Provided that Achilles did not die young, the comparison of his twelve victories, which are represented in the stele as twelve engraved crowns, to the achievements of other gladiators could suggest that he was an average athlete. $^{16}$

The stele was erected in the memory of the deceased by his companion

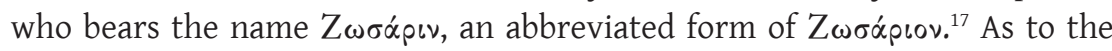
letters BEPE following her name, it is not clear to which word they belong to.

13. See Robert, Gladiateurs 298-299 (see n. 9) and G. Ville, La gladiature en occident des origins à la mort de Domitien (BEFAR 245, Rome 1981) 308; Mann, Gladiatoren 152-154 (see n. 4).

14. See Robert, Gladiateurs 297-302 (see n. 9) and Mann, Gladiatoren 152-153 (see n. 4).

15. Carter, Spectacles 295-296 (see n. 8); Mann, Gladiatoren 152-154 (see n. 4).

16. On the number of victories see Robert, Gladiateurs 294 (see n. 9); for Macedonia

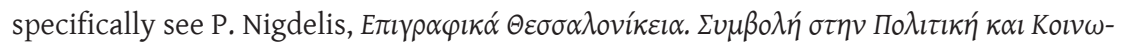

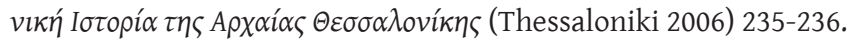

17. For the name $Z \omega \sigma \alpha$ p donia see LGPN IV s.vv. 
Since the engraver obviously committed a mistake and various restorations could be suggested, ${ }^{18}$ it would be preferable to leave the issue open.

The second funeral inscription again was found in a grave at Amphipolis, near the bridge over the Strymon River. Its gladiatorial nature is evident by the stereotypical formula $\pi \cup \gamma \mu \tilde{\omega} v$ and the depiction of the palm branch. The inscription is engraved on a white, coarse-grained, crystalline marble slab. The upper and right sides are broken. The rear and the left surfaces are roughly worked. The right forearm of a figure advancing to the left is depicted in a shallow recess. The figure holds in his hand an engraved palm branch $(\sigma \pi \dot{\alpha} \delta, \xi)$, thus it represents a gladiator "dans sa gloire", who belongs to Robert's first sub-category, namely the heavily armored gladiator. ${ }^{19}$

Archaeological Museum of Amphipolis, Inv. No. MA $\Lambda 1077=$ MK $\Lambda$ 134. Height: 0.567 m.; width: $0.23 \mathrm{~m}$.; thick: $0.075 \mathrm{~m}$. Letter height: $0.03-0.039 \mathrm{~m}$. Line spacing: $0.017 \mathrm{~m}$. (fig. 2).

$$
\begin{aligned}
& \mathrm{XPH} \quad \text { ana- [--ca 3-4-- } \\
& \text { AMA gly- [--ca 3-4-- } \\
& \Theta \Omega \text { phum [--ca3-4--] } \\
& 4 \quad \mu \nu i \alpha s[\chi \alpha \dot{\alpha} \rho \nu] \\
& \pi \cup \gamma \mu \tilde{\omega}[\nu \text { numerus]. } \\
& \mathrm{X} \alpha \tilde{i} \rho \varepsilon \pi[\alpha \rho \circ \delta i \tau \alpha] \text {. }
\end{aligned}
$$

The inscription could be dated to the second or to the third century AD on the basis of the letter forms (namely the four-bar omega, the three-bar sigma, and the angular theta), the ligatures in 11.1 and 5 as well as the square and angular forms of its lettering in general. ${ }^{20}$

18. Taking into account that companions of gladiators were usually slaves, the word BEPE might denote her legal status. In that case, we could restore the transliterated form of the latin word verna, namely bépva (a slave born in his master's household). The term is also used as a proper name in Greek as e.g. in P. Pilhofer, Philippi 2. Katalog der Inschriften von Philippi, 2. Aufl. (Tübingen 2009) 220, no. 167 (Philippi, 2nd-3rd cent. AD). In either case, the cutter would have corrected his mistake by writing the right letter in color.

19. See Robert, Gladiateurs 47-49 (see n. 9).

20. For a similar overall impression of the lettering see SEG XXX 598 (Serres, 136 


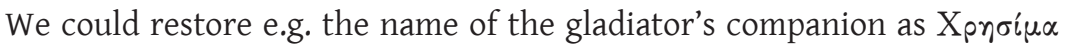
or $\mathrm{X} \rho \dot{\gamma} \sigma \tau \eta^{21}$ and the name of the deceased as 'A $\mu \alpha \rho \alpha \nu \theta_{0 \varsigma}$, a name which was actually used for other gladiators. ${ }^{22}$ The latter is according to Robert's categorization a speaking name ("nom parlants") indicating the gladiator's intention to stay alive during the combat. ${ }^{23}$

The formulaic expression $\pi \cup \gamma \mu \tilde{\omega} \nu$ followed by a number designates the total number of combats in which he had participated during his career and corresponds to its Latin equivalent "pugnarum + number". ${ }^{24}$

\author{
Pantelis Nigdelis \\ Prof. of Ancient History \\ School of History and Archaeology \\ Aristotle University of Thessaloniki \\ pnigdeli@hist.auth.gr \\ Anny Tzelepidou \\ Phd Candidate in Ancient History \\ Department of History and Archaeology \\ Aristotle University of Thessaloniki \\ tzelepidoua@yahoo.gr
}

AD), I.Leukopetra 52 (208/9 AD).

21. For these names in Macedonia see LGPN IV s.vv.

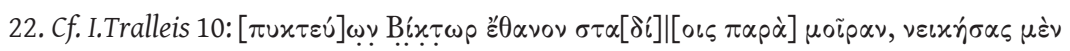

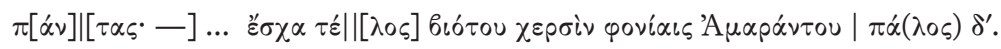

23. Robert, Gladiateurs 299-300 (see n. 9).

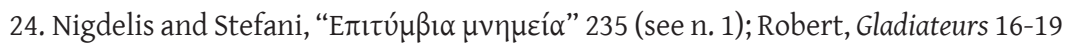
(see n. 9). 


\section{Summary}

This note presents two previously unpublished inscriptions from Amphipolis. Both of them are funerary monuments of gladiators (while the first is fully preserved, the latter has the upper and right sides broken), thus they enrich the sparse epigraphical evidence for the presence of gladiators at Amphipolis. 


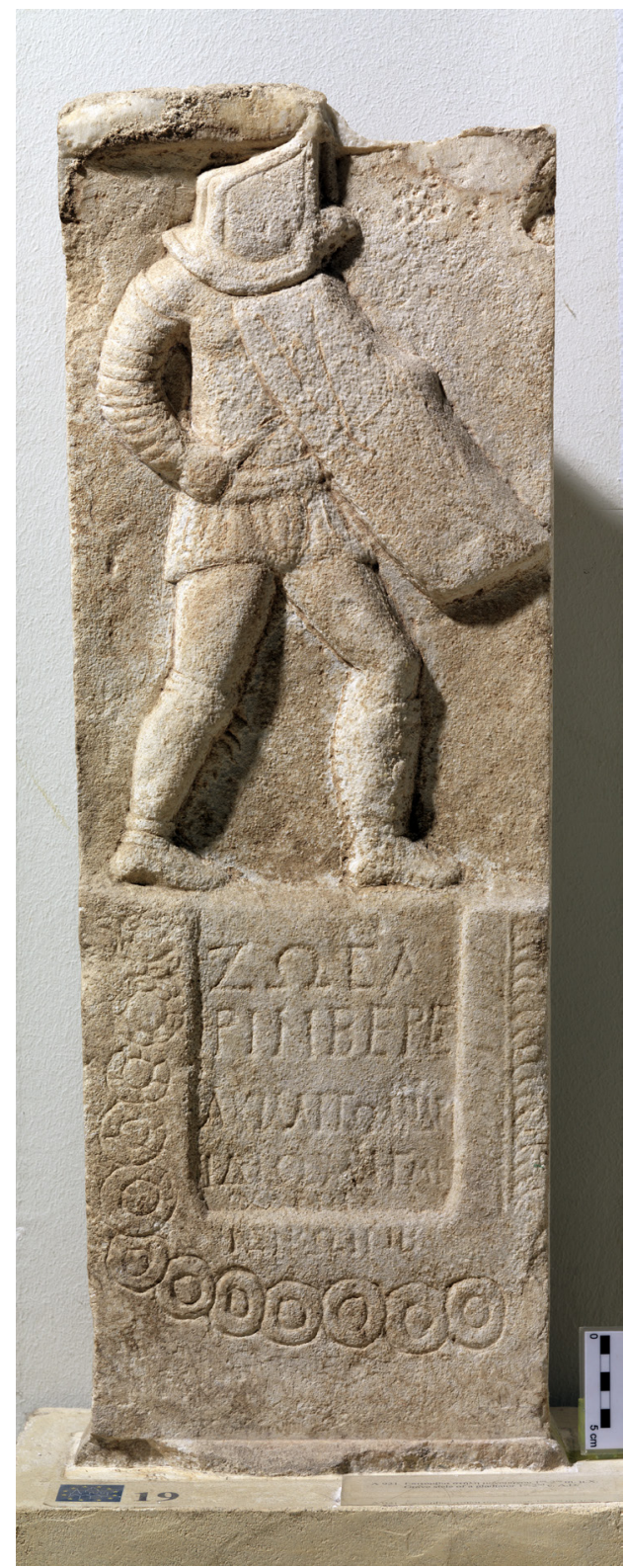

Fig. 1: The funerary stele of Achilles. 


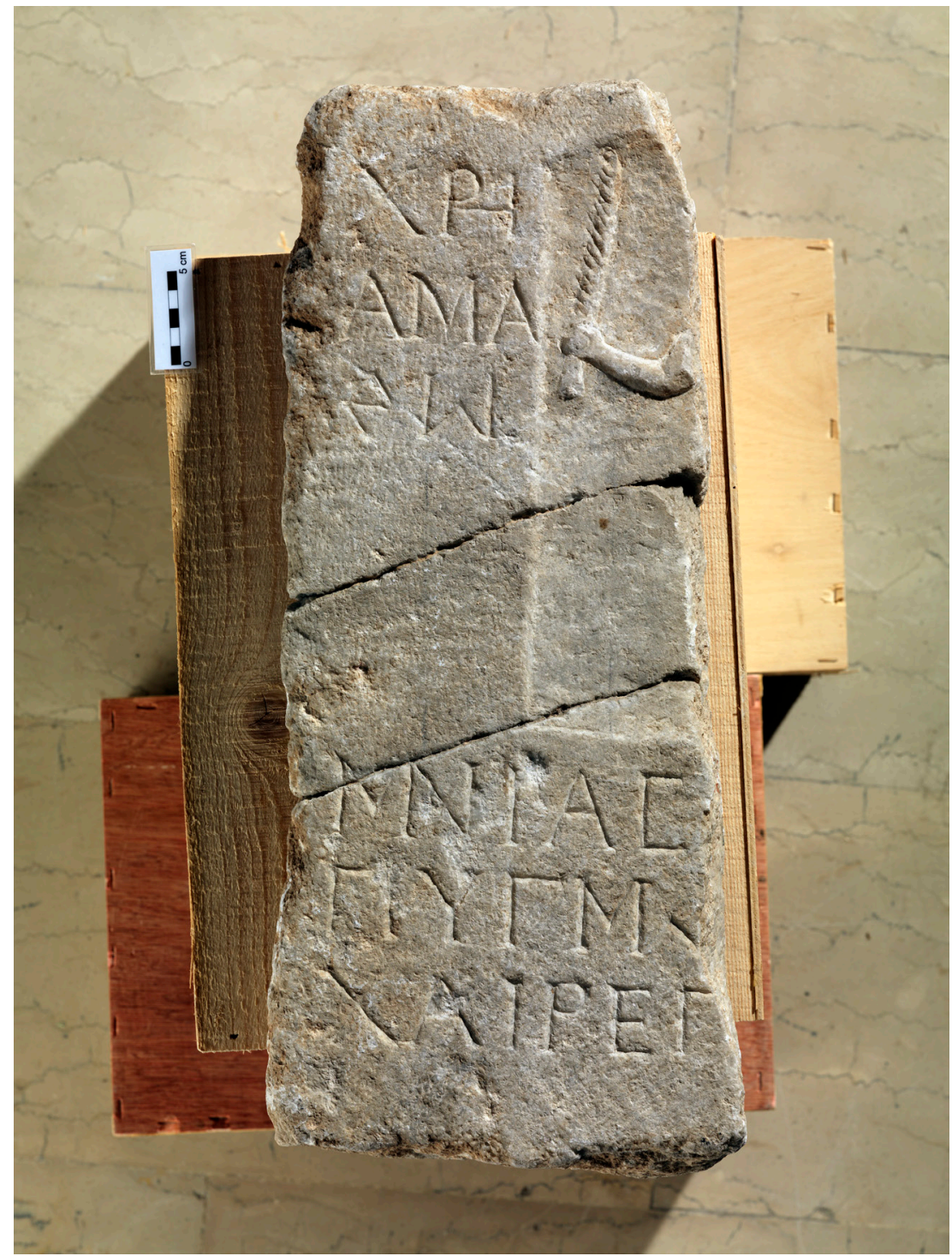

Fig. 2: The funerary stele of Amaranthus. 